University of Nebraska - Lincoln

DigitalCommons@University of Nebraska - Lincoln

Educational Psychology Papers and

Publications

Educational Psychology, Department of

1981

Prediction Analysis and Developmental Priority: A Comment on Froman and Hubert

David Moshman

University of Nebraska-Lincoln, dmoshman1@unl.edu

Follow this and additional works at: https://digitalcommons.unl.edu/edpsychpapers

Part of the Educational Psychology Commons

Moshman, David, "Prediction Analysis and Developmental Priority: A Comment on Froman and Hubert" (1981). Educational Psychology Papers and Publications. 79.

https://digitalcommons.unl.edu/edpsychpapers/79

This Article is brought to you for free and open access by the Educational Psychology, Department of at DigitalCommons@University of Nebraska - Lincoln. It has been accepted for inclusion in Educational Psychology Papers and Publications by an authorized administrator of DigitalCommons@University of Nebraska - Lincoln. 
Published in Psychological Bulletin, 90:1 (1981), pp. 185-187. Copyright (C) 1981 American Psychological Association. Used by permission. "This article may not exactly replicate the final version published in the APA journal.

It is not the copy of record.” http://www.apa.org/journals/

Submitted December 2, 1980.

I am grateful to Barbara Plake for helpful criticism of earlier drafts of this article. Correspondence: David Moshman, Department of Educational Psychology, University of Nebraska-Lincoln, Lincoln, Nebraska 68588.

\title{
Prediction Analysis and Developmental Priority: A Comment on Froman and Hubert
}

\author{
David Moshman \\ Department of Educational Psychology, University of Nebraska-Lincoln
}

\begin{abstract}
Froman and Hubert (1980) have attempted to show how recently developed prediction analysis techniques may be applied to issues of developmental priority, that is, to clarifying the interrelationship between two developing concepts. Although this work is in some respects an important advance over earlier statistical techniques, it seems to raise new problems: (a) It goes too far in identifying issues of developmental priority (sequence vs. synchrony) with issues of statistical relationship (dependence vs. independence) and thus (b) unjustifiably fails to consider certain information inherent in the data which, although irrelevant to issues of statistical relationship, is highly relevant to issues of developmental priority. The present application of prediction analysis techniques to questions of developmental priority thus raises new difficulties at least as serious as those it resolves.
\end{abstract}

In an interesting recent article, Froman and Hubert (1980) considered the application of prediction analysis techniques developed by Hildebrand, Laing, and Rosenthal (1977) to issues involving the developmental priority of concepts. These statistical techniques and their application by Froman and Hubert are particularly noteworthy in that they are not limited simply to deciding between sequence (one concept develops before another) and synchrony (two concepts emerge simultaneously) but rather can deal with more complex patterns of interrelationship of the sort discussed by Flavell (1971), Moshman (1977), Wohlwill (1973), and others. The purpose of this article is to suggest a serious problem that should be taken into account in the further development of prediction analysis and its applications to issues of developmental priority.

Consider a very simple case in which we simply assess the presence or absence of each of two concepts in a sample of subjects. Table 1 presents some hypothetical data discussed by Froman and Hubert (1980, p.138).
The data in Table 1 indicate that the majority of those (34) subjects who showed exactly one of the two concepts showed B only (32) rather than A only (2). As Froman and Hubert noted, various simple statistical techniques for testing developmental priority confirm this observation, thus supporting the conclusion that $B$ generally develops before A. (One might even suggest an invariant sequence here if one is willing to attribute the two discrepant cases to measurement error.)

Froman and Hubert argued, however, that any such conclusion would be an obvious mistake, since the data were specifically setup to reflect total independence of the two concepts (i.e., each cell frequency equals the expected frequency derivable from the marginal totals, given an assumption of independence). They then go on to present a prediction procedure that essentially overcomes this problem by comparing the various cell frequencies not directly with each other but with expected frequencies based on the marginals and an assumption of independence. 
Table 1

Hypothetical Frequency Distribution for Two Concepts

\begin{tabular}{cccc}
\hline & \multicolumn{3}{c}{ Concept A } \\
\cline { 2 - 4 } Concept B & Absent & Present & Total \\
\hline Absent & 8 & 2 & 10 \\
Present & 32 & 8 & 40 \\
Total & 40 & 10 & 50 \\
\hline
\end{tabular}

Though this new procedure initially sounds reasonable, it suffers from a serious confusion of developmental priority (sequence vs. synchrony) with statistical relationship (independence vs. dependence). Paradoxical as it may seem, statistical independence does not rule out developmental priority, and the present hypothetical data are a clear example of this. With respect to independence, the relatively large number of subjects in the B-only cell (32) can be dismissed as an artifact of the unequal marginals and thus does not count as contrary evidence. With respect to developmental priority, however, an appeal to the marginals will not do, since the marginals themselves reflect developmental priority: The majority of subjects show B (see row totals) but only a minority show A (see column totals), suggesting a tendency for B to develop first in the population of which the present subjects constitute a sample. Any analysis of cell frequencies which "corrects" for these marginals is correcting for actual evidence of developmental priority and thus reduces the probability of reaching the appropriate conclusion.

The importance of this problem is illustrated in Froman and Hubert's discussion of my (1977) data. Froman and Hubert maintained on the basis of a detailed prediction analysis that the Common Sense I (CSI) model provides at least as good a fit for the data as the consolidation $(\mathrm{C})$ model that I find more convincing. Intuitively, their conclusion is surprising, since the two models differ only with respect to a single cell (see their Figure 5 , p. 144); the actual number of subjects falling in that cell is quite small, conforming to the prediction of the $\mathrm{C}$ model. Froman and Hubert (1980) argued, however, that their analysis avoids the statistical traps that have ensnared others:

In particular, significant differences be-
tween off-diagonal cells is insufficient for
the establishment of developmental prior-
ity, since any statement on a temporal order
of acquisition must account for the cell fre-
quencies that are expected under statistical
independence,(p. 145)

Thus the apparent support for the $\mathrm{C}$ model is seen as an artifact of the unequal marginal totals. The problem with their conclusion is that the $\mathrm{C}$ and CSI models actually make different predictions about the marginal totals themselves. For example, it is clear from Froman and Hubert's Figure 5 (p. 144) that the C model (but not the CSI model) predicts that for each of the two sections in their Table 3 (p. 144), the marginal total for the second row exceeds the marginal total for the second column (reflecting the underlying prediction of $\mathrm{C}$ theory that subjects remain transitional longer on the negated version of each task). It is thus not surprising that after "correcting" for marginal totals that support the $\mathrm{C}$ model, the support of the data for that model is considerably attenuated.

Though there seems to be a serious problem with the prediction analysis approach, the present critique should not be construed as suggesting that the earlier approaches Froman and Hubert criticized were unproblematical. In fact, at a deeper theoretical level, Froman and Hubert may well be on the right track. Clearly, our ultimate goal in research on developmental priority is not to establish a static cross-classificational picture but rather to better understand the intricate causal dynamics linking the development of various concepts. Thus we need to consider the directional or reciprocal dependence of the concepts under consideration. However, the prediction analysis approach seems to get at issues of dependence only at the expense of ignoring orthogonal issues of developmental priority. Moreover, statistical dependence is relevant here only to the extent that it reflects an underlying causal-developmental dependence, and in the absence of longitudinal and 
experimental data, this is a difficult thing to judge. Unless prediction analysis can be further developed to deal with these issues, its application to questions of developmental priority raises new difficulties at least as serious as those it resolves.

\section{References}

Flavell, J. H. Stage-related properties of cognitive development. Cognitive Psychology, 1971, 2, 421-453.
Froman, T., \& Hubert, L. J. Application of prediction analysis to developmental priority. Psychological Bulletin, 1980, 87, 136-146.

Hildebrand, D., Laing, M., \& Rosenthal, A. Prediction analysis of cross classifications. New York: Wiley, 1977.

Moshman, D. Consolidation and stage formation in the emergence of formal operations. Developmental Psychology, 1977, 13, 95-100.

Wohlwill, J. F. The study of behavioral development. New York: Academic Press, 1973. 